\title{
Selected Cribroperidinium species (Dinophyceae) from the Kimmeridgian and Volgian of northwest Europe
}

\author{
DAVID A. BAILEY \\ BioStrat Services Limited, Myrtle Cottage, \\ Penny Bridge, Ulverston, \\ Cumbria LA12 7RJ, England.
}

\begin{abstract}
Two new dinoflagellate species, Cribroperidinium complexum and C. erymnoseptum are described from the Kimmeridgian of the Norwegian Continental Shelf and Spitzbergen. The morphotypes described as Cribroperidinium sp. A by Davey (1982) from the Portlandian of Denmark, are thought to be conspecific with Cribroperidinium gigas Raynaud 1978. The holotype of Cribroperidinium longicome (Downie) Lentin \& Williams 1985 has been examined and is discussed. J. Micropalaeontol., 12 (2): 219-7. December 1993.
\end{abstract}

\section{INTRODUCTION}

During palynological analysis of Late Jurassic (Kimmeridgian - Volgian) sediments from the Norwegian continental shelf and Spitzbergen, significant numbers of the genus Cribroperidinium were observed. Two species; C. erymnoseptum sp. nov. and C. complexum sp. nov. are introduced here. Other species, including C. longicorne (Downie) Lentin \& Williams 1985 and C. gigas (Raynaud) Helenes 1984, were also recorded and are discussed in the following systematic palynology section. Type and illustrated material is from three localities (Figure 1); well $7120 / 12-2$ in the Barents Sea, well 2/1-8 in the Gyda Field and outcrop material from the Janusfjellet Formation at Myklegardfjellet, Svalbard. Type material is stored in the slide collection of BP Norway, Forusbeen 35, 4033 Forus, Stavanger.

The species "Gonyaulacysta" gigas was introduced by Raynaud (1978) from the Kimmeridgian and Volgian of the North Sea and adjacent areas. Subsequently, Davey (1982) described a similar form as Cribroperidinium sp. A from the Volgian to Ryazanian of the Haldager No. 1 borehole in Denmark. Whilst Davey compared this morphotype to Cribroperidinium longicorne (Downie) Lentin \& Williams 1985, which is also similar, he did not refer to C. gigas. Lentin \& Williams (1981), transferred the species C. gigas to Millioudodinium, and it was most recently transferred to Cribroperidinium by Helenes (1984), who considered it to be a "provisionally assigned species". It is proposed that $C$. gigas and Cribroperidinium sp. A are conspecific, although published and unpublished literature has tended to ignore C. gigas in favour of Cribroperidinium sp. A Davey. (eg. Riley et al. 1989, Riding \& Thomas 1988). The synonymy is formally discussed in the following systematic palynology section.

\section{SYSTEMATIC PALYNOLOGY}

Division Pyrrhophyta Pascher 1914

Class Dinophyceae Fritsch 1929

Order Peridiniales Haeckel 1894

Family Gonyaulacaceae Lindemann 1928

Genus Cribroperidinium Neale \& Sarjeant 1962 , emend Helenes 1984

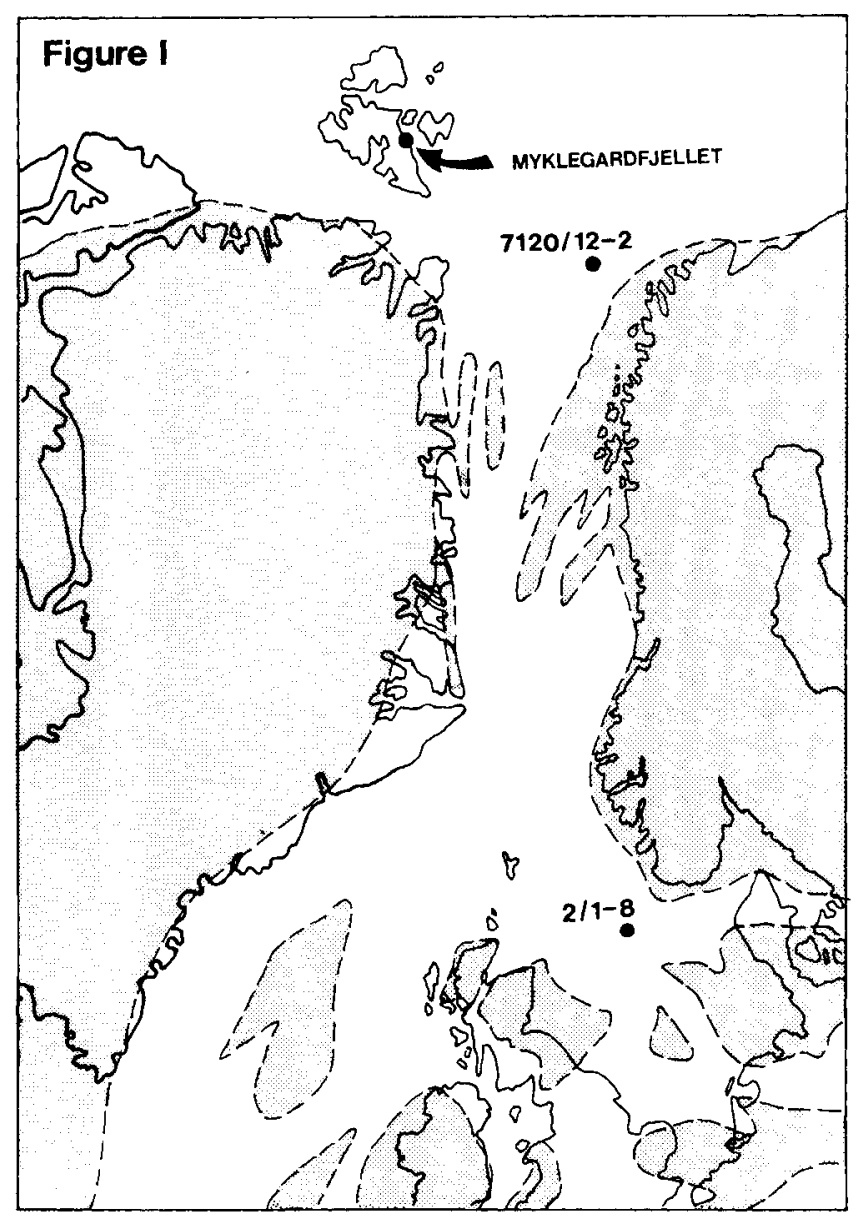

Fig. 1. Sample localities for studied material. Late Jurassic palaeogeography (shaded) modified from Larsen (1987).

\section{Cribroperidinium complexum sp. nov. \\ (Pl. 1, Figs 1-9)}

Diagnosis. A large species of Cribroperidinitm, hypocyst broadly rounded, epicyst merging into a pronounced apical horn which is terminated by a complex apicular structure, composed of interlinking trabeculate elements. Sexiform gonyaulacoid 
paratabulation expressed by parasutural crests or ridges, which often develop proximate vacuoles and/or distal trabeculae. Parasutural features are more strongly expressed antapically and along the paracingulum. Surface of autophragm scabrate to granulate. Precingular archaeopyle, type $P\left(3^{\prime \prime}\right)$.

Size range. $80 \mu-130 \mu$ overall length (holotype $122 \mu \times 98 \mu$ ).

Holotype. Slide NBS 1838, England Finder Q33/4.

Type locality. Norsk Hydro Norwegian Well 7120/12-2, at 1838m (Hekkingen Formation).

Derivation of name. After the complexly structured apical hom. Remarks. The apical horn is variably developed (compare Pl. 1, Figs 2 and 6). It is always surmounted by a complex apicular structure composed of trabeculate elements. No intratabular ridges or crests have been observed and there are no small dorsal intercalary plates (Pl. 1, Fig 9).

Comparison. Cribroperidinium complexum sp. nov. is easily identified by its characteristic apical horn, style of parasutural ornament and large size. Cribroperidinium gigas (Raynaud) Helenes 1984 is often of similar overall shape, but the horn, although long and terminated by a solid extension, is not ornamented by trabeculate elements. In addition, C. gigas has a thicker wall, ornamented by spines. Cribroperidinium longicorne (Downie) Lentin \& Williams 1985 is usually smaller, with a thin wall and poorly defined paratabulation.

Occurrence. The author has observed this species in sediments of Kimmeridgian age from Spitzbergen (Janusfjellet Formation) and from the Kimmeridgian of well 7120/12-2 in the Barents Sea, where it occurs commonly at some levels. It has also been observed in Kimmeridgian sediments from the Halten Terrace, though it has not been recorded in the North Sea or further south. The early Kimmeridgian age interpretation for these sediments is based on the co-occurrence of other stratigraphically diagnostic dinoflagellate cysts. In the Barents Sea material, C. complexum was observed in conjunction with Gonyaulacysta jurassica, Endoscrinium luridum, Rhynchodiniopsis cladophora, Geiselodinium sp., Perisseiasphaeridium pannosum, Ambonosphaera staffinensis and Atopodinium haromense. In Spitzbergen, C. complexum was recorded in a number of outcrop samples of the Janusfjellet Formation. The assemblages here were quite poor, with Horologinella spinosigibberosa, Paragonyaulacysta borealis, Pareodinia ceratophora, Aldorfia dictyota, Atopodinium haromense and Cribroperidinium ehrenbergi group sensu Helenes (1984). In the Haltenbanken area of the Norwegian Sea, C. complexum has been observed in core material with Gonyaulacysta jurassica, Perisseiasphaeridium pannosum, Oligosphaeridium patulum, Cribroperidinium longicorne, Paragonyaulacysta capillosa, Rhynchodiniopsis cladophora and Geiselodinium paeminosum.

\section{Cribroperidinium erymnoseptum sp. nov.}

(Pl. 2, Figs 1-9)
Diagnosis. A species of Cribroperidinium with a subspherical to ovoidal body, surmounted by a small apical horn. Sexiform Gonyaulacoid paratabulation is expressed by variably developed parasutural features of generally low relief. These comprise an assortment of irregular arched/trabeculate crests, spines, and columns, which may be capitate, echinate and bifurcate distally. Similar features are developed as growth lines on intratabular areas. Archaeopyle precingular, type $\mathrm{P}\left(3^{\prime \prime}\right)$. Size range. $50 \mu-80 \mu$ overall length (holotype $78 \mu \times 57 \mu$ ).

Holotype. Slide 41818.3, England Finder R53

Type locality. BP Norwegian Well 2/1-8 at $3937.40 \mathrm{~m}$ (core, Farsund Formation).

Derivation of name. Greek erymnos, fenced, fortified, strong. With reference to the robust, fence-like parasutural features. Remarks. The hypocyst and epicyst are of more or less equal proportions, separated by a slightly laevorotary paracingulum. The short apical horn is solid and may be simple, spinose or capitate. The parasutural ornament is variably developed, from rows of spines or columns, aligned along paraplate boundaries to complex fence-like crests, comprising arched and trabeculate elements. The crests are generally $2-4 \mu$ in height, but can be over $5 \mu$ on the hypocysts of some strongly ornamented specimens.

Comparison. Cribroperidinium erymnoseptum sp. nov. differs from other species of the genus by the characteristic parasutural features and smooth autophragm. Some of the more ornamented forms are similar to Exiguisphaera phragma Duxbury 1980, but do not have 2P archaeopyles and have coarser, more robust parasutural ornament.

Occurrence. The author has recorded C. erymnoseptum from the Kimmeridgian of the North Sea. In the type material, numerous specimens were observed, associated with a rich and diverse marine microflora, including; Endoscrinium luridum, Gonyaulacysta jurassica, Geiselodinium sp., Oligosphaeridium patulum, Perisseiasphaeridium pannosum, Scriniodinium inritibilum, Glossodinium dimorphum, Pareodinia ceratophora, Prolixosphaeridium granulosum, abundant Circulodinium distinctum group sensu lato, and common Cribroperidinium ehrenbergi group sensu Helenes (1984).

\section{Cribroperidinium gigas (Raynaud 1978) Helenes 1984.} (Fig. 2, Figs 1-4)

1978 Gonyaulacysta gigas Raynaud, p.392-393, pl. 2, fig. 16, textfig. 5.

1982 Cribroperidinium sp. A Davey, p. 27, pl. 10, figs. 5, 6. 1981 Millioudodinium gigas (Raynaud) Lentin \& Williams 1984 Cribroperidinium? gigas (Raynaud) Helenes, p. 128. 1987 Cribroperidinium sp. A Davey 1982, Heilmann-Clausen, pl. 10, fig.6

\section{Explanation of Plate 1}

Cribroperidinium complexum sp. nov.

Fig 1, ventral focus, note trabeculate parasutural features at lower left, x600, Figs 2, 3, holotype, 2,x600, 3, x1000, Figs 4, 5, lateral view, $4, \times 600,5, \times 1000$, Fig 6, lateral view of specimen with a long apical horn, x600, Figs 7, 8, large specimen with trabeculate parasutural ornament on the antapical pole, 7, dorsal focus, x600, 8, ventral focus, x600, Fig 9, dorsal view, note precingular archaeopyle, x600 All specimens from the Hekkingen Formation (Kimmeridgian) in Well N7120/12-2. 

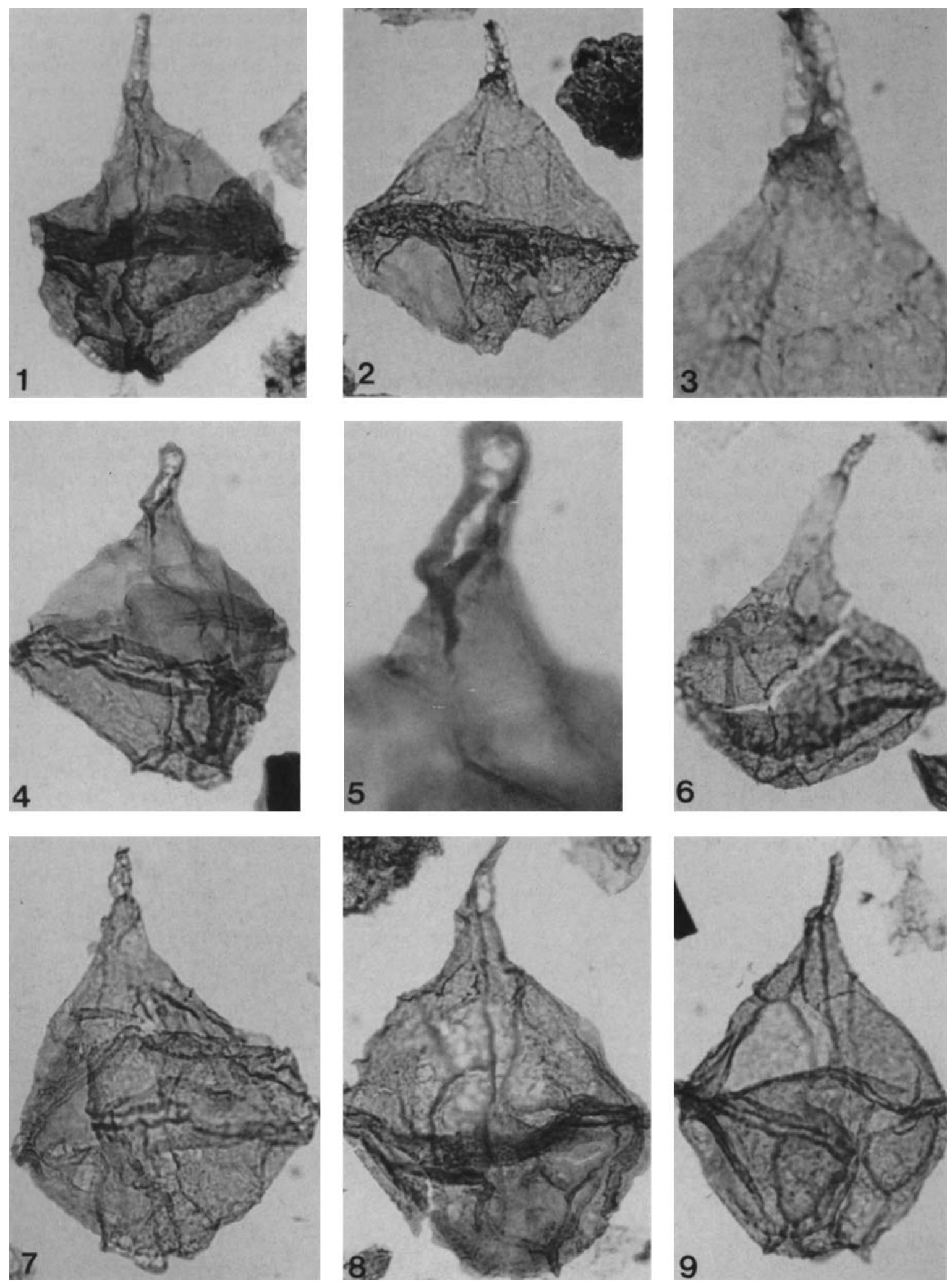
1987 Cribroperidinium gigas (Raynaud), Heilmann-Clausen, $\mathrm{pl}$. 10, fig. 13

1989 Cribroperidinitum sp. A Davey 1982, Barron, pl. 1, figs. 2, 3 Diagnosis. (Translation from Raynaud 1978, p. 392-393) "A species of large proportions. Body spherical to ovoidal, with a thick and granulose wall, sometimes bearing short spines. Very long, almost smooth apical horn, with dimensions equal to approximately two-fifths of the total length. Cingulum and tabulation marked by thick crests."

Remarks. Davey (1982) gives a very similar description for Cribroperidinium sp. A, and it is proposed that this form is conspecific with C. gigas. Helenes (1984) considered this to be a "provisionally assigned species". The morphology of this species is very variable, both in overall shape, length of apical horn and development of spines/ornament.

Occurrence. Previous published records of this taxon include late Volgian/ early Ryazanian to earliest middle Volgian (Riley et al., 1989), late Ryazanian to early Portlandian of the Haldager No. 1 borehole and earliest Portlandian (albani Zone) of southern England (Davey 1982) and Portlandian to Kimmeridgian of the North Sea (Raynaud 1978). The present author has observed C. gigas from the Kimmeridgian to latest Volgian of the North Sea. The species may be abundant in the lower part of the Late Volgian and upper part of the Middle Volgian. Raynaud (1978) did not record C. gigas from any of his outcrop material in the UK, but saw frequent specimens from the North Sea. Davey (1982) however, observed large numbers of "Cribroperidinium sp. A" from the anguiformis-okusensis (giganteus), oppressus and primitious Zones of eastern England, and from the early Portlandian of the Haldager No. 1 borehole, Denmark.

\section{Cribroperidinium longicorne (Downie 1957) Lentin \& Williams 1985}

(Pl. 3, Figs 1-6)

1957 Gonyaulacysta longiconnis Downie, p. 420, pl. 20, fig. 8, textfig. $2 \mathrm{a}, \mathrm{b}$.

1982. Millioudodinium longicornis (Downie) Sarjeant, p. 39. 1985 Cribroperidinium? longicorne Lentin \& Williams, p. 79.

Remarks. Lentin \& Williams (1985, p.79) state "Because of the uncertainty as to the tabulation mode, we consider the present generic assignment provisional". The present author has examined the holotype of $C$. longicorne, which has a thin, pale wall and the paratabulation is only partially discernible. The apical horn is hollow for approximately half its length, terminating in a solid,flexuose extension. Short spinules are developed at gonal points, only rarely along parasutures. Intratabular areas are finely granular. Because of the very faint paratabulation, precise details of paratabulation, such as the presence or absence of dorsal intercalary paraplates on the epicyst, or of L-type ventral organisation were not discernible. The author has observed many specimens comparable with the holotype, and also transient morphotypes between C. longicorne and members of the C. ehrenbergi group Helenes (1984). Specimens intermediate between $C$. gigas and C. longicorne have also been observed.

Occurrence. There have been many published records of this useful stratigraphic marker species, including more recently; Kimmeridgian (hudlestoni to cymodoce Zones) of southern and eastern England (Riding and Thomas 1988, Riding 1987), middle Kimmeridgian to early Volgian of the North Sea (Riley et al. 1989), middle to early Kimmeridgian of the southwestern North Atlantic (Zotto et al. 1987), Kimmeridgian (mutabilis Zone) of southern Germany (Dürr 1987), Kimmeridgian (mutabilis Zone) of southern England (Nøhr-Hansen 1986).

\section{ACKNOWLEDGEMENTS}

The author is grateful to Norsk Hydro and BP Exploration for permission to publish. Thanks to the University of Sheffield, Centre for Palynological Studies, for access to their type collection. Thanks also to the Editor and referees of the Journal of Micropalaeontology.

\section{Manuscript received November 1992 \\ Manuscript accepted August 1993}

\section{REFERENCES}

Barron, H. F., 1989. Dinoflagellate cyst biostratigraphy and palaeoenvironments of the Upper Jurassic (Kimmeridgian to basal Portlandian) of the Helmsdale region, east Sutherland, Scotland, Chapter 9 in Batten, D. J. and Keen, M. C. (Eds.), Northtwest European Micropalaeontology and Palynology, Ellis Horwood.

Davey, R. J., 1982. Dinocyst stratigraphy of the latest Jurassic to Early Cretaceous of Haldager No. 1 borehole, Denmark. Geological Survey of Denmark, Series B, No. 6: 1-57.

Downie, C., 1957. Microplankton from the Kimmeridge Clay, Geological Society of London, Quarterly Journal, 112: 413-434.

Dürr, G., 1987. Dinoflagellaten-Zysten aus dem Weissjura $\partial$ (Mittelkimmeridgien) der westlichen Schwäbischen Alb (Süddeutschland). Neues Jahrbuch für Geologie und Paläontologie, Abhandlungen, 176(1):67-80.

Heilmann-Clausen, C., 1987. Lower Cretaceous dinoflagellate biostratigraphy in the Danish Central Trough, Danmarks Geologiske Undersogelse Series A, No. 17.

Helenes, J., 1984. Morphological analysis of Mesozoic-Cenozoic Cribroperidinium (Dinophyceae), and taxonomic implications. Palynology. 8: 107-137.

Larsen, V. B., 1987. A synthesis of tectonically-related stratigraphy in the North Atlantic-Arctic region from Aalenian to Cenomanian time. Norsk Geologisk Tidsskrift, 67: 281-293.

\section{Explanation of Plate 2}

Cribroperidinium erymnoseptum $\mathrm{sp}$. nov

Figs 1, 2, holotype, dorsal view, x600, Fig 3, lateral view of broken specimen, $x 600$., Fig 4, dorsal view of specimen with reduced ornament, $x 600$, Fig 5, specimen with complex parasutural ornament, x600, Fig 6, dorsal focus, $x 600$, Figs 7-9, views of specimen with very ornate and complex parasutural crests, note the smooth autophragm, 7, 9, x600, 8, x1000 All specimens from the Farsund Formation in well N2/1-8. 

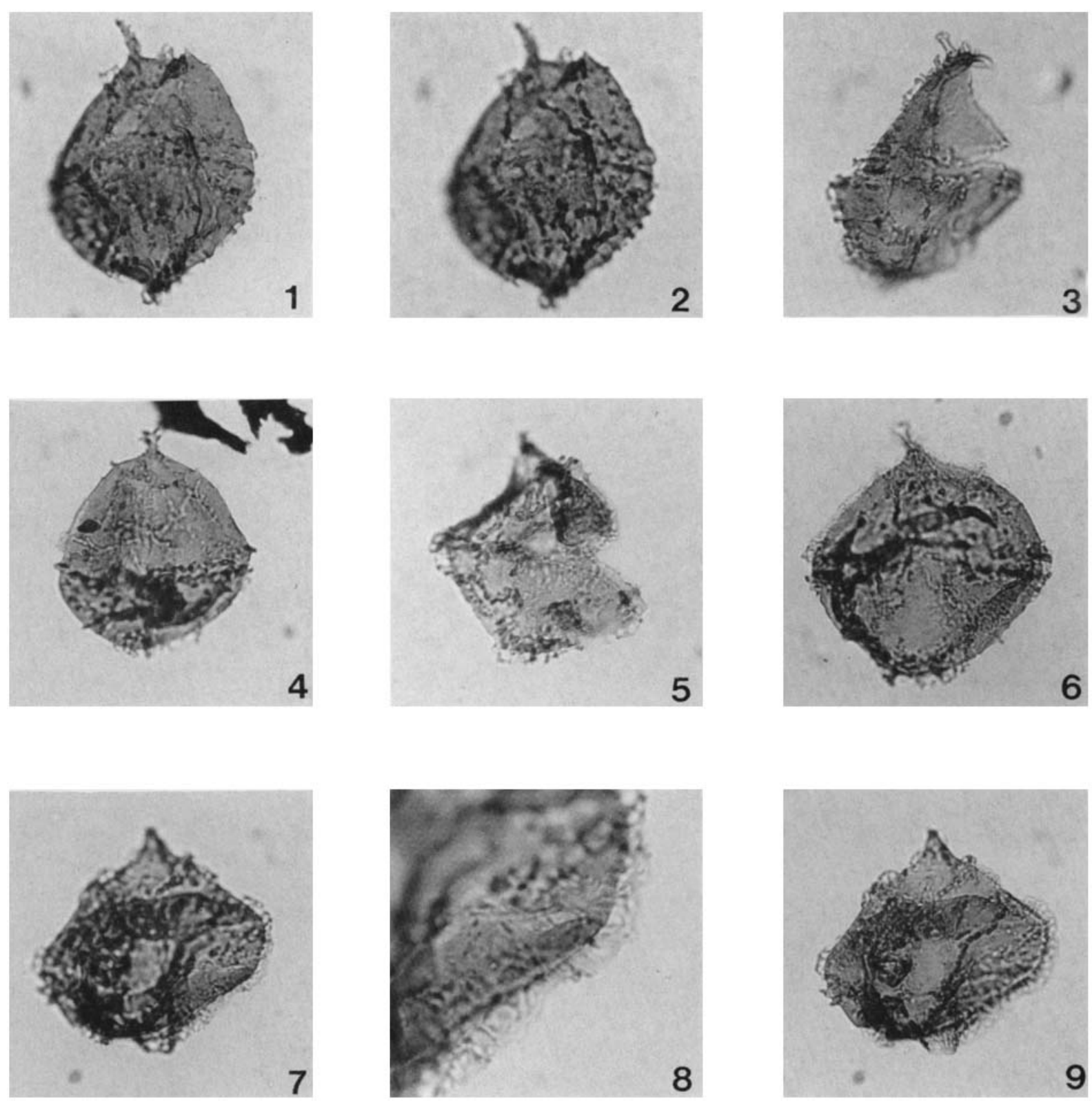
Lentin, J. K. and Williams, G. L., 1985. Fossil dinoflagellates: index to genera and species, 1985 edition. Canadian Technical Report of Hydrography and OceanSciences. No. 60: 1-449.

Nehr-Hansen, H., 1986. Dinocyst stratigraphy of the Lower Kimmeridge Clay, Westbury, England. Geological Society of Denmark, Bulletin 35: 31-51.

Raynaud, J. F., 1978. Principaux dinoflagellés characteristiques du Jurassique supérieur d'Europe du Nord. Palinologia, Número Extraordinario, No. 1, 387-405.

Riding, J. B., 1987. Dinoflagellate cyst stratigraphy of the Nettleton Bottom Borehole (Jurassic: Hettangian to Kimmeridgian), Lincolnshire, England. Proceedings of the Yorkshire Geological Society, 46(3): 231-266.
Riding, J. B. and Thomas, J. E., 1988. Dinoflagellate cyst stratigraphy of the Kimmeridge Clay (Upper Jurassic) from the Dorset Coast, southern England. Palynology, 12: 65-88.

Riley, L. A., Roberts, M. J. and Connel, E. R., 1989. The application of palynology in the interpretation of Brae Formation stratigraphy and reservoir geology in the South Brae Field, British North Sea. Correlation in Hydrocarbon Exploration. Norwegian Petroleum Society, (Graham \& Trotman), p. 339-356.

Zotto, M., Drugg, W. S. and Habib, D., 1987. Kimmeridgian dinoflagellate stratigraphy in the southwestern North Atlantic. Micropaleontology, 33: 193-213.
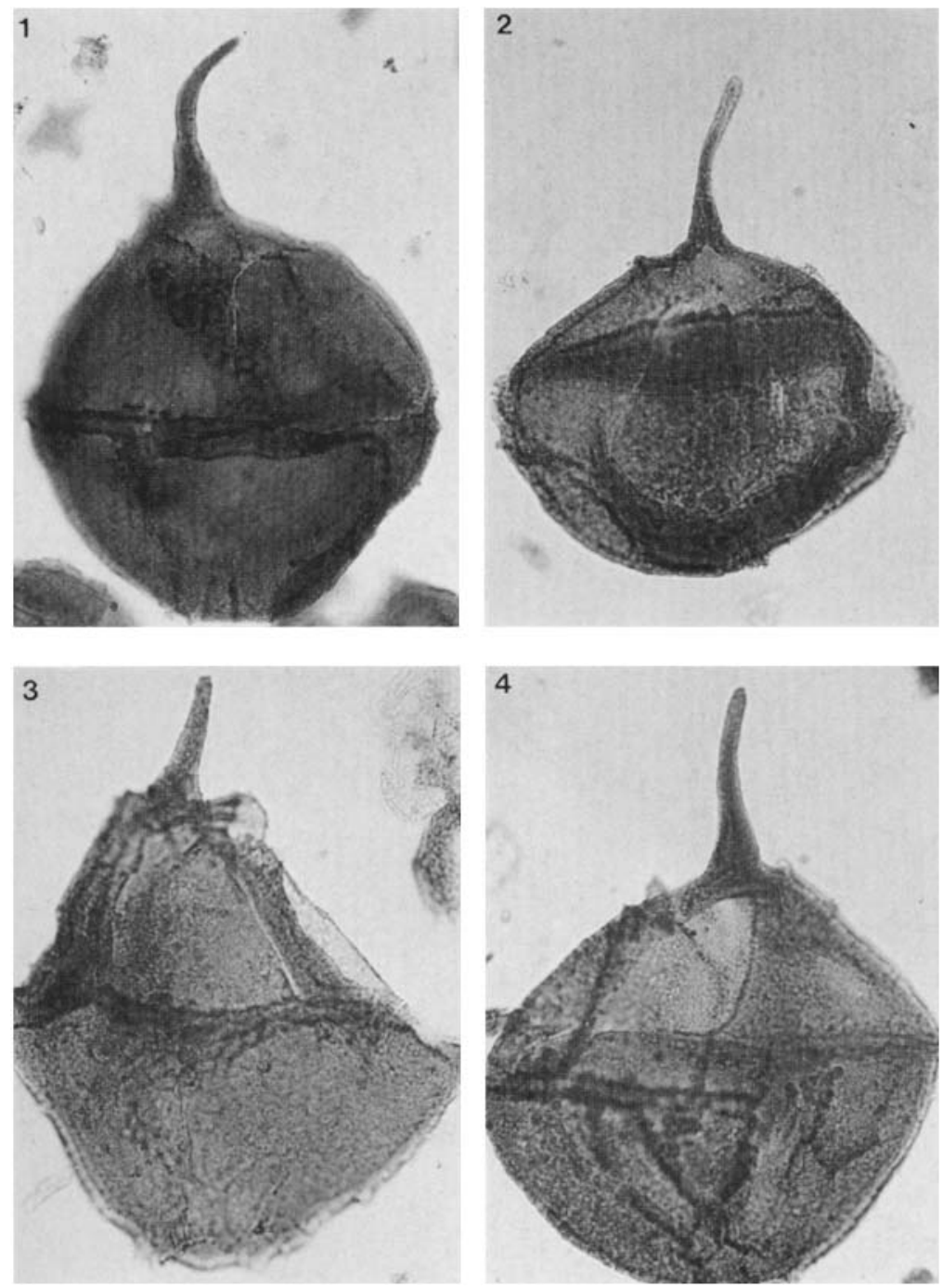

Fig. 2 Cribroperidinium gigas (Raynaud) Lentin \& Williams 1985. Fig 1, left dorsal view of specimen with operculum in place and thick, densely ornamented wall,x600 (approx.). Fig 2, dorsal view, x600 (approx.). Fig 3, left lateral view, x600 (approx.). Fig 4, dorsal view $x 600$ (approx.). All specimens from the latest Middle Volgian of the Central North Sea.

\section{Explanation of Plate 3}

Cribroperidinium longicome (Downie) Lentin and Williams 1985. Figs 1-3, holotype, slide KL 11.15, Kimmeridge Clay at Setchey, Norfolk, England. Fig 2, enlargement of apical horn showing the hollow proximal and solid distal portions, x1000. Figs 4-6, Kimmeridge Clay of the Central North Sea, $\times 600$. 

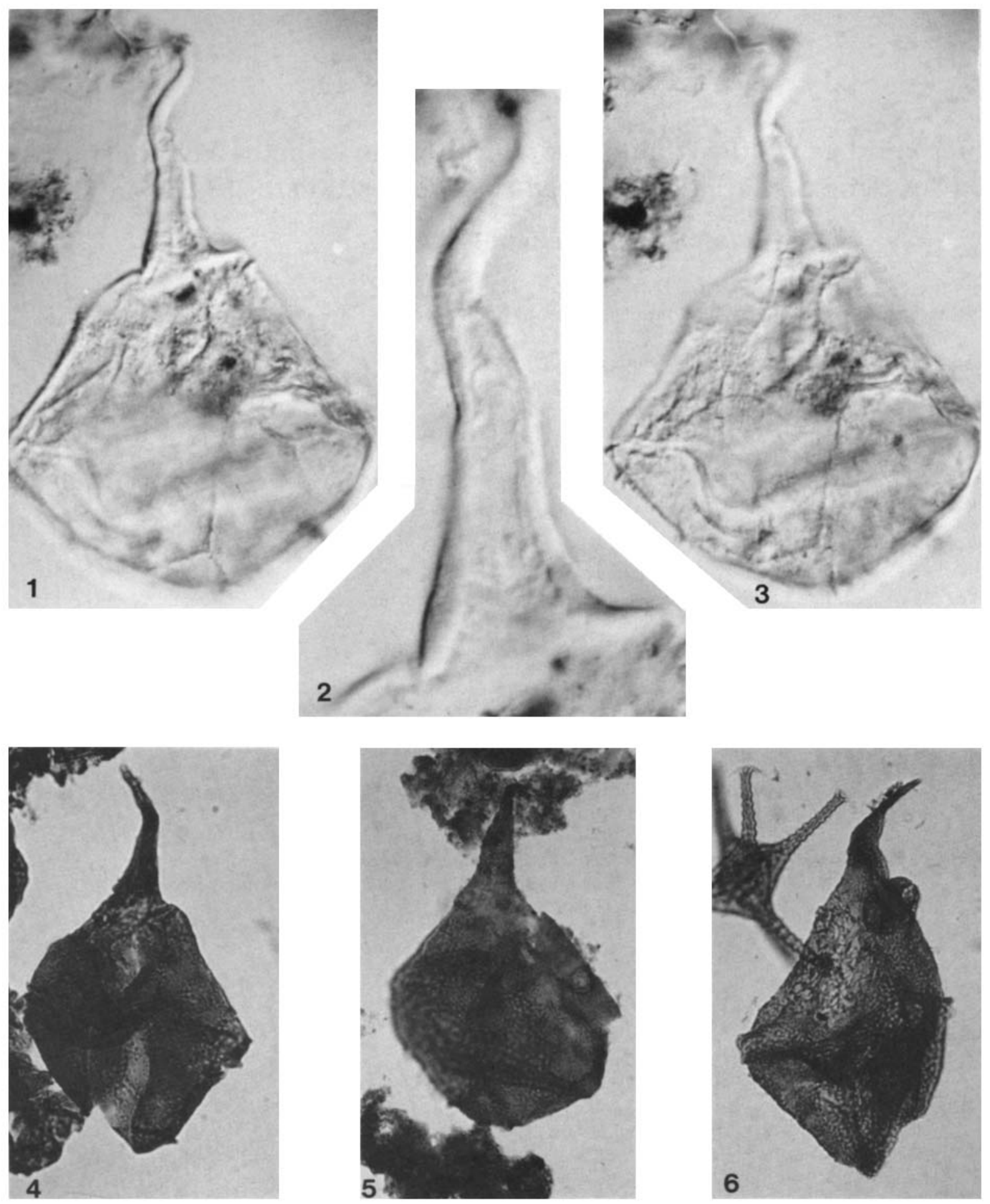